\title{
RECOGNITION OF THE RED CROSS OF EQUATORIAL GUINEA
}

Geneva, 29 September 1994

Circular No. 579

To the Central Committees of the

National Red Cross and Red Crescent Societies

Ladies and Gentlemen,

We have the honour to inform you that the International Committee of the Red Cross has officially recognized the Red Cross of Equatorial Guinea. This recognition, which took effect on 28 September 1994, brings to 163 the number of National Societies that are members of the International Red Cross and Red Crescent Movement.

The new National Society applied for recognition by the ICRC on 10 January 1994. In support of its application it submitted various documents, including a report on its activities in 1993 and the text of its statutes. The Society had previously been recognized by Presidential Decree No. 98 of 16 October 1985, in accordance with the provisions of the Geneva Conventions, as the only Red Cross Society auxiliary to the public authorities and authorized to extend its activities throughout the territory.

The various documents submitted, which were examined by the ICRC and the International Federation of Red Cross and Red Crescent Societies within the Joint ICRC/Federation Commission for National Society Statutes, showed that the ten conditions for recognition of a new National Society by the International Committee had been fulfilled. 
The Republic of Equatorial Guinea had deposited its instruments of accession to the four Geneva Conventions of 12 August 1949 with the Swiss Federal Council, the government of the depositary State, on 24 July 1986 and had thus become party to them on 24 January 1987 . Equatorial Guinea has also acceded to the Additional Protocols of 1977.

During a visit to the Society, representatives of the ICRC and the Federation ascertained that the Society has a sound structure enabling it to work throughout the national territory. It is currently engaged in activities in several spheres: training first-aid workers and running first-aid posts, providing health education and recruiting blood donors. Its Red Cross Youth members help with protecting and restoring the environment.

The Society is presided over by Dr Elías-Manuel Maho Sicachá. Its headquarters is in Malabo. The address is as follows:

\section{Red Cross of Equatorial Guinea \\ Calle Abilio Balboa 92 \\ Malabo \\ Equatorial Guinea}

The International Committee of the Red Cross has pleasure in welcoming the Red Cross of Equatorial Guinea to membership of the International Red Cross and Red Crescent Movement. It hereby accredits it and commends it to all other National Societies, and wishes it every success in continuing and developing its humanitarian work.

\section{FOR THE INTERNATIONAL COMMITTEE OF THE RED CROSS}

\section{Cornelio Sommaruga \\ President}

